\author{
Marta Wiszniewska ${ }^{1}$ \\ Diana Tymoszuk ${ }^{1}$ \\ Cezary Pałczyński \\ Jolanta Walusiak-Skorupa ${ }^{1}$
}

\title{
WORK-RELATED SYMPTOMS AMONG WORKERS EXPOSED TO BLACK TEA DUST
}

\author{
OBJAWY ZWIĄZANE Z PRACĄ U PRACOWNIKÓW EKSPONOWANYCH NA PYŁ CZARNEJ HERBATY
}

\author{
${ }^{1}$ Nofer Institute of Occupational Medicine / Instytut Medycyny Pracy im. prof. J. Nofera, Łódź, Poland \\ Clinic of Occupational Diseases and Toxicology, Department of Occupational Diseases / Klinika Chorób Zawodowych i Toksykologii, \\ Oddział Chorób Zawodowych \\ ${ }^{2}$ Nofer Institute of Occupational Medicine / Instytut Medycyny Pracy im. prof. J. Nofera, Łódź, Poland \\ Clinic of Occupational Allergology and Environmental Health / Klinika Alergologii i Zdrowia Srodowiskowego
}

\begin{abstract}
Background: Tea may be classified as unfermented green, semi-fermented oolong and fermented black. All of these types are derived from Camellia sinensis, the Tea Plant, which contains the low molecular weight (LMW) agent Epigallocatechin gallate (EGCg), probably responsible for allergic reactions. The aim of our study was to asses the work-related allergic symptoms and IgE-mediated sensitivity among black tea packers. Material and Methods: Study groups comprised 26 black tea packers (group 1) and 20 office workers (group 2). A questionnaire, skin prick tests (SPTs) to common allergens and black tea, evaluation of specific IgE (asIgE) to Camellia sinensis and moulds, pre- and post-work-shift spirometry were performed. Results: At least 1 symptom suggesting allergic disease was reported by $85 \%$ of the tea packers and $60 \%$ of the office workers. The most frequent positive results of SPTs were obtained with moulds (8\%). A small decline in FEV (forced expiratory volume in $1 \mathrm{~s}$ ) after the work shift was observed among tea packers sensitized to moulds. Conclusions: Although specific sensitization to black tea was not observed in our study groups, cough and skin symptoms were significantly more frequently among the tea packers than in office workers. The irritant impact on the airways and the skin of tea dust and/or sensitization to moulds contaminating tea leaves are being suspected. Med Pr 2015;66(1):11-15
\end{abstract}

Key words: occupational allergy, black tea dust, sensitization to moulds, microbial contamination of tea, work-related symptoms

\section{STRESZCZENIE}

Wstęp: Herbatę można sklasyfikować jako niesfermentowaną zieloną, częściowo sfermentowaną oolong i w pełni sfermentowaną czarną. Wszystkie wymienione typy herbaty otrzymuje się z rośliny Camellia sinensis, która zawiera czynnik o małej masie cząsteczkowej - galusan epigalokatechiny (Epigallocatechin gallate - EGCg) o potencjale alergizującym. Celem badania było scharakteryzowanie związanych z pracą objawów sugerujących schorzenia alergiczne oraz ocena statusu immunologicznego pakowaczy czarnej herbaty. Material i metody: Zbadano 26 pakowaczy czarnej herbaty (grupa 1) oraz 20 pracowników biurowych (grupa 2). U wszystkich badanych przeprowadzono badanie ankietowe dotyczące objawów oraz punktowe testy skórne (skin prick tests - SPTs) z alergenami pospolitymi i czarną herbatą, oznaczono poziom swoistych przeciwciał w klasie IgE dla rośliny Camellia sinensis i pleśni oraz wykonano badanie spirometryczne przed zakończeniem i po zakończeniu zmiany roboczej. Wyniki: Występowanie co najmniej 1 objawu sugerującego alergię zgłosiło $85 \%$ pakowaczy herbaty i $60 \%$ pracowników biurowych. Najczęściej obserwowanym uczuleniem w wynikach punktowych testów skórnych wśród pakowaczy herbaty było uczulenie na pleśnie (8\%). U tych pracowników obserwowano także spadek natężonej 1-sekundowej objętości wydechowej (FEV - forced expiratory volume in 1 s) po zakończeniu zmiany roboczej w stosunku do wartości wyjściowych. Wnioski: Kaszel i objawy skórne zdecydowanie częściej występowały u pakowaczy herbaty niż u pracowników biurowych, chociaż w żadnej z badanych grup nie wykazano uczulenia na alergeny czarnej herbaty. Nie można jednak wykluczyć drażniącego działania pyłu herbacianego na drogi oddechowe i skórę oraz uczulenia na grzyby pleśniowe zanieczyszczające liście herbaty. Med. Pr. 2015;66(1):11-15

Słowa kluczowe: alergia zawodowa, pył czarnej herbaty, uczulenie na pleśnie, mikrobiologiczne zanieczyszczenie herbaty, objawy związane z pracą

Corresponding author / Autorka do korespondencji: Agnieszka Lipińska-Ojrzanowska,

Nofer Institute of Occupational Medicine, Department of Occupational Diseases,

św. Teresy 8, 91-348 Łódź, Poland, e-mail: lipinska@imp.lodz.pl

Received: 2014, July 1, accepted: 2014, October 1

Funding / Finansowanie: by European Funds Human Capital Programme (POKL/profil/2008-2013) "Development of complex preventive programs". Project coordinator: Prof. Jolanta Walusiak-Skorupa, MD, PhD. 


\section{INTRODUCTION}

All types of tea are derived from Camellia sinensis, the Tea Plant. The method of processing tea leaves allows to classify tea as unfermented green, semi-fermented oolong and fermented black tea. The major catechine contained in tea leaves is called Epigallocatechin gallate (EGCg). It is a low molecular weight (LMW) agent that is probably able to induce allergic IgE-mediated bronchial and skin reactions. The contents of EGCg in various tea types is different ( $8 \%$ in green, $4 \%$ in oolong and $1 \%$ in black) $[1,2]$. Moreover, fungi have been isolated in all of the steps of processing tea leaves (withering, fermentation, firing, sorting, packaging) [3].

It is known that workers exposed to various organic dusts may develop respiratory symptoms and functional changes deteriorating airways $[4,5]$.

The aim of the study was to evaluate the work-related allergic symptoms, immunological status and lung function among workers packaging dried black tea in relation to office workers employed at the same industrial plant.

\section{MATERIAL AND METHODS}

A cross-sectional study was conducted at a tea-packaging factory in Poland. Study groups consisted of one day 1st-shift workers who participated in the examination voluntarily and comprised 26 operators working on tea bag production lines and 20 office employees. All of the production lines were equipped with local ventilation. Half-face protective dust masks were available only for operators, although their application was not obligatory. All of the subjects underwent a detailed questionnaire [6], physical examination and rest spirometry using the MicroLab Spirometer (MicroMedical, England). Atopy was assessed by skin testing.

Skin prick tests (SPTs) to common allergens (tree and grass pollens, weeds, Dermatophagoides pteronyssinus, Dermatophagoides farinae, moulds (Allergopharma, Germany) and feathers (Stallergenes, France) were performed on the flexor surface of the forearms using commercial extracts and standardised disposable lancets (Allergopharma, Germany). Moreover, all of the subjects underwent SPT with black tea (Stallergens, France). All of the SPTs included positive $(10 \mathrm{mg} / \mathrm{ml}$ histamine hydrochloride, Stallergenes, France and Allergopharma, Germany) and negative controls (phenylated glycerol-saline, Stallergenes, France and Allergopharma, Germany).
The results of the SPTs were assessed after $15 \mathrm{~min}$. A positive reaction was defined as a wheal of at least $3 \mathrm{~mm}$ in diameter. Venous blood samples in the amount of $5 \mathrm{ml}$ were collected to test for the presence of specific immunoglobulin E antibodies (asIgE) against tea (Rf 222) and fungi (mx2: Penicillium chrysogenum, Candida albicans, Alternaria alternata, Setomelanomma rostrata, Cladosporium herbarum, Aspergillus fumigatus) by the commercial fluoroenzymeimmunoassay method (ImmunoCap, Phadia, Sweden). A cut off value for asIgE detection was $0.35 \mathrm{kU} / \mathrm{l}$ with the sensitivity range at the level of $84-95 \%$ and the specificity range at the level of $85-94 \%$ [7]. Subjects had been avoiding steroids, antihistamines or antidepressants for at least one month before testing and they did not report any acute viral infections at that time.

The study protocol was approved by the Bioethical Committee at the Nofer Institute of Occupational Medicine in Łódź, Poland. The workers were informed about the research process and methods in a written manner. Participation in the study was voluntary and required informed consent.

Statistical analysis was performed using Statistica 8. Chi-square test (or Fisher's exact test) and Wilcoxon rank sum were used to compare the tea packers and office workers.

A p-value $<0.05$ was considered as a significant.

\section{RESULTS}

The groups were similar in relation to age, sex, smoking habits, presence of pets at home and the family history of atopy. The average period of employment in the tea factory was longer among the office workers (group 2) in comparison to the tea packers (group 1), while their daily time of exposure to tea dust amounted to more than $5 \mathrm{~h}$ per group 1 in comparison to group 2 . At least 1 symptom suggesting allergic disease was reported by $85 \%$ of the tea packers and $60 \%$ of the office workers, out of which at least one developed after the beginning of employment in $73 \%$ and $45 \%$ of the subjects, respectively. The most common were respiratory symptoms.

Group 1 suffered mainly from cough and group 2 from rhinitis (Table 1). In both groups, women suffered from respiratory ailments more often than men: 9 women (35\%) and 3 men (12\%) among the operators, 7 women $(35 \%)$ and 2 men (10\%) among the office workers group. At least one result of the SPT to common allergens was positive in $12 \%$ of the tea 
Table 1. Characteristics of the study group

Tabela 1. Charakterystyka grupy badanej

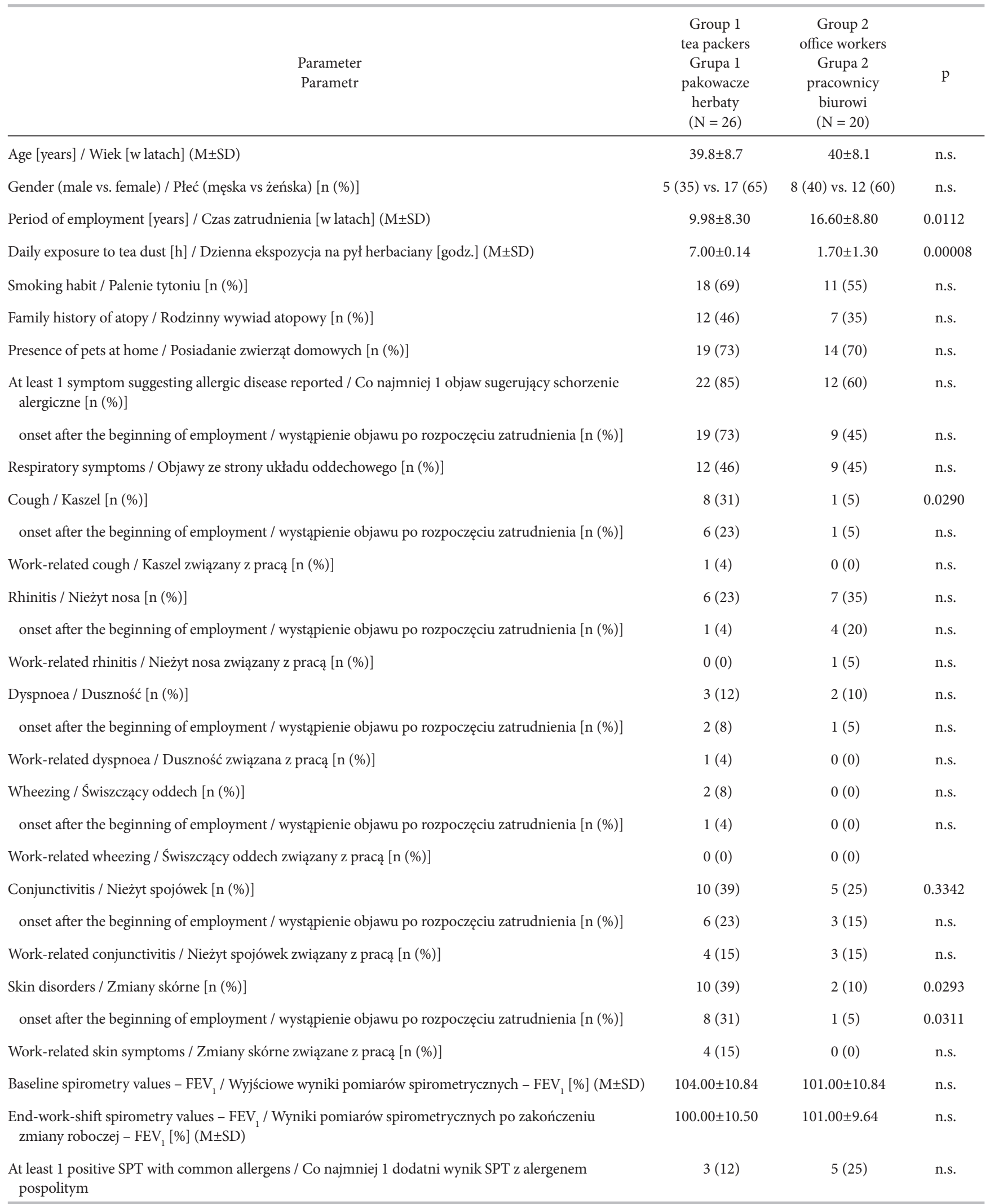

M - mean / średnia, SD - standard deviation / odchylenie standardowe, n.s. - not statistically significant / nieistotne statystycznie, FEV 1 - forced expiratory volume in 1 s / natężona 1-sekundowa objętość wydechowa, SPT - skin prick test / punktowy test skórny. 


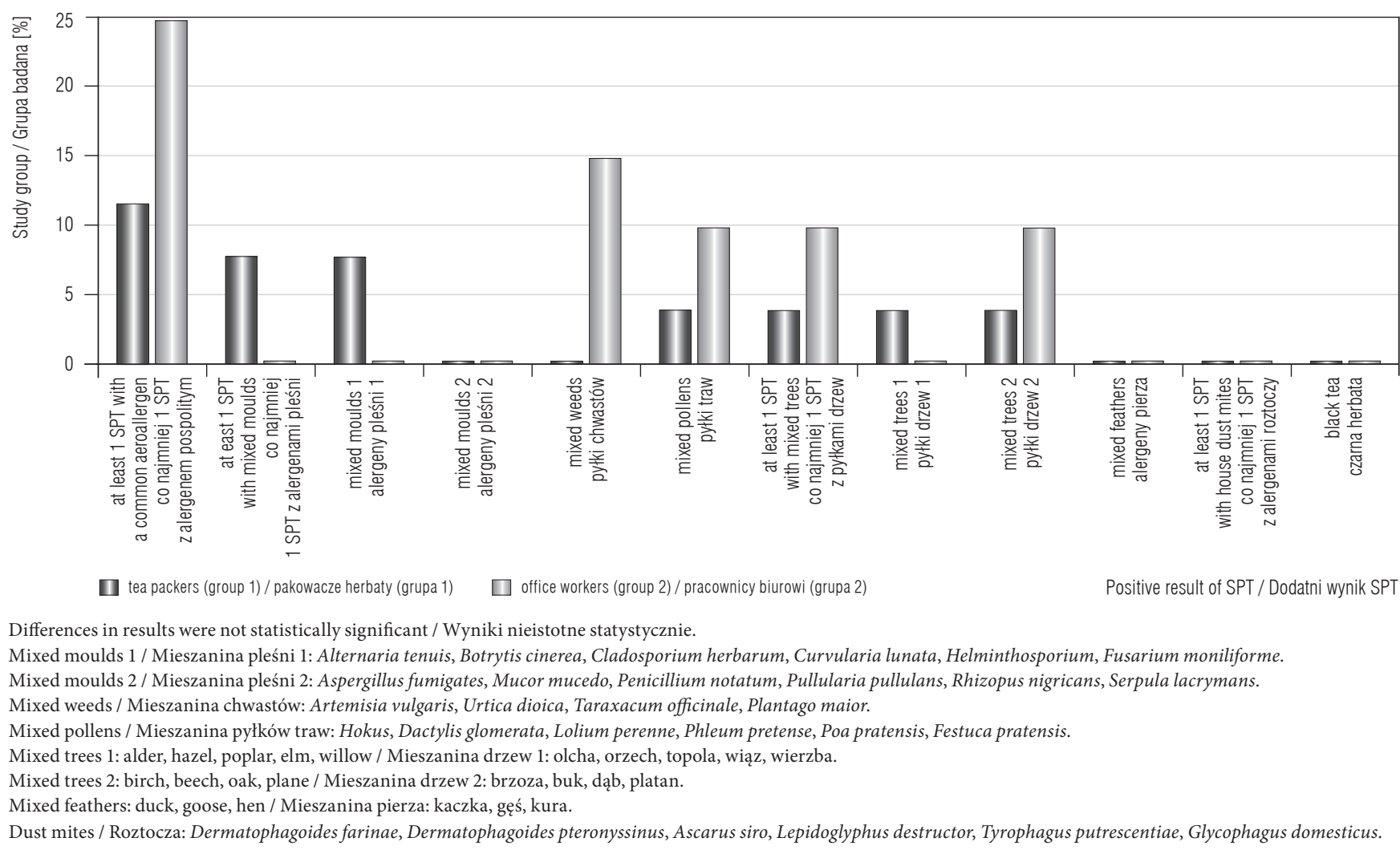

Fig. 1. Prevalence of sensitization to common allergens in skin prick tests (SPT)

Ryc. 1. Wyniki punktowych testów skórnych (SPT) z alergenami pospolicie występującymi w środowisku komunalnym

packers and $25 \%$ of the office workers. The most common IgE-mediated skin sensitization among black tea packers was induced by moulds (8\%) and weeds among office workers (15\%) (Figure 1).

Specific sensitization to black tea was not observed in the study groups. All of the examined subjects had baseline spirometry parameters within normal range. Changes in the forced expiratory volume in $1 \mathrm{~s}\left(\mathrm{FEV}_{1}\right)$, before and after the work-shift, were generally not statistically important among office workers (the mean $\mathrm{FEV}_{1}$ observed amounted $0.7 \%$ ) and tea packers (the mean $\mathrm{FEV}_{1}$ amounted 4\%), however, a small decline of the $\mathrm{FEV}_{1}$ values was observed in 2 tea operators sensitized to moulds with the maximum fall of $11 \%$ and $17 \%$. In the sera of these subjects, asIgE against moulds $(\mathrm{mx} 2)$ were detected at the concentrations corresponding to class $2(0.83 \mathrm{U} / \mathrm{ml}$ and $1.02 \mathrm{U} / \mathrm{ml}$, respectively).

\section{DISCUSSION}

In our study, tea packers reported potential work-related allergic symptoms more frequently than office workers. Despite the fact that we did not find any evi- dence of any specific IgE-sensitization to black tea, an occupational allergy could not be excluded. Voluntary participation in the examination might have resulted in losing many symptomatic workers due to concerns about their further employment. What is more, allergic response to such LMW agents as EGCg can be dosedependent and black tea contains lower concentration of it than other tea types.

The principal limitation of our study was the lack of possibility to obtain both data about dust measurements in the breathing zone in the factory and tea leave samples from the employer. Not having performed an inhalant test for bronchial hyperresponsiveness at the workplace was also a technical limitation.

Similarly to other studies $[8,9]$, tea workers more often suffered from respiratory ailments than the controls. Just as in the study performed by Mirbod et al. [10] who assessed the health conditions of 36 male and 27 female workers involved in green tea production procedures, women had a significantly higher prevalence rate for respiratory symptoms than men (approximately 26\% and $6 \%$ reported shortness of breath). Likewise in the Abramson's et al. research [9], the prevalence of allergy to 
fungi was no greater than in the general community, but in our study, due to the observed decline in $\mathrm{FEV}_{1}$ between pre- and post-work-shift spirometry among tea packers sensitized to moulds, we suggest that it could be responsible for respiratory symptoms. A few studies reported the presence of fungal species in black tea, e.g., Aspergillus, Penicillium, Cladosporium, Alternaria, Fusarium, Rhizopus [11-13]. Mycoflora contamination of the Indian black tea was mostly dominated by Aspergillus [14].

\section{CONCLUSIONS}

In conclusion, we did not find evidence of any specific IgE-induced sensitization to black tea among the production line operators. A not statistically significant $4 \%$ fall in the mean value of FEV among tea workers at the end of the work shift in comparison to the baseline parameters seems to be rather a random variation than the result of non-specific irritant impact of organic dust on airways. However, the role of sensitization to mould-contaminated tea leaves in work-related respiratory symptoms could not be excluded.

\section{ACKNOWLEDGMENTS}

The authors wish to thank Mrs. Bożena Jung and Mrs. Jolanta Wojno-Kulińska for performing skin prick tests and spirometry, and MSc Ewa Nowakowska-Świrta for immunologic assays.

\section{REFERENCES}

1. Ikegaya K, Nakagawa M. Healthy and useful components of green tea. In: Ohishi S, editor. All about Japanese tea. 8th ed. Shizuoka: Shizuoka Tea Association; 1998. p. 500-2.

2. Shiari T, Sato A, Hara Y. Epigallocatechin gallate the major causative agent of green tea-induced asthma. Chest. 1994;106:1801-5, http://dx.doi.org/10.1378/chest.106.6.1801.

3. Elshafie A, Al-Lawatia T, Al-Bahry S. Fungi associated with black tea and tea quality in the Sultanate of Oman. Mycopathologia. 1999;145:85-93, http://dx.doi. org/10.1023/A:1007034729467.

4. Zuskin E, Kanceljak B, Schacter E, Mustajnegovic J. Respiratory function and immunologic status in workers processing dried fruits and teas. Ann Allergy Asthma Immunol. 1996;77(5):417-22, http://dx.doi.org/10.1016/ S1081-1206(10)63341-8.

5. Jawardana P, Uduphilie M. Ventilatory function in workers exposed to tea and wood dust. Occup Med. 1997;47: 105-9, http://dx.doi.org/10.1093/occmed/47.2.105.

6. Vandenplas O, Ghezzo H, Munoz X, Moscato G, Perfetti $\mathrm{L}$, Lemiere $\mathrm{C}$, et al. What are questionnaire items most useful in identifying subjects with occupational asthma? Eur Respir J. 2005;26(6):1056-63, http://dx.doi.org/10.118 3/09031936.05.00024705.

7. ImmunoCAP specific IgE. Expected test values [Internet] [cited 2012 July 5]. Availabe from: http://www.phadia. com/Global/A\%20Document\%20Library/Allergy/Promotion\%20Material/Product\%20and\%20Assay\%20Sheets/ Assays/AssaySheet_ImmunoCAP_Specific_IgE.pdf.

8. Minov J, Karadzinska-Bislimovska J, Vasilevska K, Riteska-Kuc S, Stoleski S. Occupational asthma in subjects occupationally exposed to herbal and fruit tea dust. Arh Hig Rada Toksikol. 2007;58:211-21, http://dx.doi. org/10.2478/v10004-007-0016-4.

9. Abramson M, Sim M, Fritschi L, Vincent T, Benke G, Rolland M. Respiratory disorders and allergies in tea packers. Occup Med. 2001;51(4):259-65, http://dx.doi. org/10.1093/occmed/51.4.259.

10. Mirbod S, Fujita S, Miyashita K, Inaba R, Iwata H. Some aspects of occupational safety and health in green tea workers. Ind Health. 1995;33(3):101-17, http://dx.doi. org/10.2486/indhealth.33.101.

11. Monbaliu S, Wu A, Zhang D, Peteghem C, Saeger S. Multimycotoxin UPLC-MS/MS for tea, herbal infusions and the derived drinkable products. J Agric Food Chem. 2010;58:12664-71, http://dx.doi.org/10.1021/jf1033043.

12. Mishra B, Gautam S, Sharma A. Microbial decontamination of tea (Camellia sinensis) by gamma radiation. J Food Sci. 2006;71:151-6, http://dx.doi.org/10.1111/j.17503841.2006.00057.x.

13. Halweg H, Podsiadło B. [The microflore of tea]. Acta Mycologica. 1991-1992;XXVII:115-20. Polish.

14. Al-Sohaibani S, Murugan K, Lakshimi G, Anandraj K. Xerophilic aflatoxigenic black tea fungi and their inhibition by Elettaria cardamomum and Syzygium aromaticum extracts. Saudi J Biol Sci. 2011;18:387-94, http://dx.doi. org/10.1016/j.sjbs.2011.06.005.

The use of the article "Work-related symptoms among workers exposed to black tea dust" is available in Open Access model and permitted under license conditions of Creative Commons Attribution-NonCommercial 3.0 (also known as CC-BY-NC), available at http://creativecommons.org/licenses/ by-nc/3.0/pl/ or another language version of this license or any later version of this license published by Creative Commons / Zezwala się na korzystanie z artykułu „Objawy związane z pracą u pracowników eksponowanych na pył czarnej herbaty” w modelu open access na warunkach licencji Creative Commons Uznanie autorstwa - Użycie niekomercyjne 3.0 (znanej również jako CC-BY-NC), dostępnej pod adresem http://creativecommons.org/licenses/ by-nc/3.0/pl/ lub innej wersji językowej tej licencji, lub którejkolwiek późniejszej wersji tej licencji, opublikowanej przez organizację Creative Commons. 